\title{
THE INFLUENCE OF MOTIVATION AND WORKLOAD ON EMPLOYEE PERFORMANCE IN HOSPITAL
}

\author{
Tiara Putri Ryandini ${ }^{1 *}$, Mokhamad Nurhadi $^{2}$ \\ ${ }^{1,2}$ STIKES Nahdatul Ulama, Tuban \\ Email* : tiara.putriyandini16@gmail.com
}

\begin{abstract}
Introduction: Improved hospital performance can improve employee performance. The better employee performance, the more services provided to patients Employee performance is influenced by work motivation. The purpose of this study was to analyze the effect of motivation on employee performance. Methods: This research uses a quantitative descriptive design with a cross-sectional approach. The number of respondents in this study was 79 employees. Data were analyzed using correlation analysis. Motivation is assessed by questionnaire and performance evaluation uses observation sheets. Results: Employee motivation and performance are included in the high category (82.3\%) and (92.4\%). There is a significant influence between motivation on employee performance $(r=0.775 p(0,00)<0,05)$. The effect of intrinsic motivation $(r=0.737)$ is stronger than extrinsic motivation $(r=0.325)$. There is the influence of sub-variable responsibility $(p=0.032)$, recognition $(p=0.002)$, work performance $(p=0.007)$, career development $(p=0.000)$, work $(p=0.016)$, promotion $(p=0.029))$ working conditions $(p=0.001)$ on employee performance. Conclusions: Overall there is a strong influence on the work motivation of hospital employees. Work motivation still needs to be maintained and improved for better employee performance.
\end{abstract}

Keywords: employee performance; extrinsic motivation; intrinsic motivation; workload

\section{INTRODUCTION}

Performance appraisal is an employee performance control process that is evaluated based on certain standards. Performance appraisals are carried out effectively to direct nurses' behaviour to produce high-quality services. Also, performance appraisals are carried out to motivate employees to carry out their duties and realize hospital goals. The benefits of performance appraisal are used to improve work performance, compensate for adjustments, need for development, and see deviations or errors in work (Badi'ah, 2009). These uses require that performance appraisals can provide an accurate and objective picture of employee work performance (Tarigan, 2013). Related research on the effects of workload on their health (Bowling, Alarcon, Bragg, \& Hartman, 2015). More specifically, workload is greater than physical workers (Kawada et al., 2010; Rummell, 2015) and psychological health (Hakanen, Bakker, \& Schaufeli, 2006; Mansour \& Tremblay, 2016). Other studies also relate to stress-related burdens and correlate negatively with individual functioning (Rabe, Giacomuzzi,
\& Nübling, 2012). Indeed, the demand for workresource models (Demerouti, Nachreiner, Bakker, \& Schaufeli, 2001) expresses the demand for an energetic process, which is in accordance with the demand for work (for example, work work) which leads to results that benefit the individual and offer an energetic to cope with completion this work (Schaufeli \& Bakker, 2004).

The results of observations made previously by researchers at the time of the internship regarding employee performance at the Hospital showed that employees had an important role in providing health services at the hospital. It is shown by the increase in BOR (Bed Occupancy Ratio) every year with an average BOR reaching $87.94 \%$ which indicates that hospital performance has improved. The increase in hospital performance can be influenced by improved employee performance. The hospital currently has 20 beds with 111 permanent and non-permanent employees. In the process of developing the Hospital in 2019, it will be converted into a public hospital with 50 beds so that there will be additional employees according 
to the needs and abilities of the hospital. Besides, there are still some employees who are burdened with multiple tasks because of the limited resources they have so that many employees still hold concurrent positions and assignments. The number of tasks and responsibilities given to employees causes the results achieved to be less than the maximum because employees only have little time to complete many tasks. Not yet implemented the job description that has been made to the maximum by the hospital employee will have an impact on the results of the performance evaluation as an evaluation material for hospital management. Efforts should be made to motivate employees to be able to carry out their duties properly by the specified job description. If this is not done it will have an impact on decreasing the quality of work and the declining quality of health services which so far has been quite good.

Motivating efforts are made to improve employee work performance by their respective duties. Employees at the Hospital currently have career development through training programs and higher-level education. Opportunities to join the development program are still limited and not all employees have the same opportunity. Employees are also not given a direct reward for their achievements so there is no recognition of their achievements. Although there is a point counting system for additional services provided at the end of the year as a form of award given indirectly. Also, opportunities for the promotion of higher levels are still very limited even though they have been arranged by the hospital management. Individual motivation is influenced by two factors, namely intrinsic factors and extrinsic factors. Intrinsic factors include achievement, self-recognition, the nature of work responsibilities and career development while extrinsic factors include salary, work environment, work relationship (Tarigan, 2013). Herzberg's theory also states that performance is influenced by motivating factors manifested in success, appreciation, responsibility, work, and self-development. This theory explains that with intrinsic changes the factor of job satisfaction can be motivated. While extrinsic factors are only factors that are preventing work dissatisfaction (van Herpen, van Praag, \& Cools, 2005). The working environment at the Nahdlatul Ulama Hospital is also less conducive because of limited space for employees, which results in employees not being able to do their jobs more freely. Examining the background above, researchers are interested in researching the effect of motivation on employee performance at the hospital. The purpose of this study was to analyze the effect of motivation on employee performance.

\section{METHODS}

This study uses a cross-sectional approach. The sample in this study were 79 hospital employees by established criteria. The instruments used in this study were motivationa questionnaires, time and motion study questionnaires and professional performance standards questionnaires. All of the questionnaire was valid used to measure (Nursalam, 2016). Analysis of the data used in univariate analysis and bivariate analysis. Univariate analysis is used to determine the frequency of the variables to be examined by making a range of scores on each variable. Bivariate analysis is used to test hypotheses between two variables that are thought to influence by using the Spearman correlation. The data collection phase begins with an explanation of the aims and objectives of this study to respondents. Primary data collection is done by giving questionnaires directly to respondents and awaited by researchers to finish. The employee performance observation sheet is filled in by the director, section head and subsection head in the hospital by first making a long time filling agreement because it cannot be completed in a short time. This study was approved by the Institute of Health Research 
Ethics, School of Health Sciences NU Tuban No.

003 / LEPK. STIKESNU / IX / 2019.

\section{RESULTS}

Table 1. Characteristics of hospital employee respondents in 2019

\begin{tabular}{lcc}
\hline \multicolumn{1}{c}{ Characteristics } & n & \% \\
\hline Gender & 31 & 39.2 \\
- Male & 48 & 60.8 \\
- Female & & \\
\hline Education Level & 18 & 22.8 \\
- Junior / senior high school & 39 & 49.4 \\
- Diploma & 22 & 27.8 \\
- Bachelor / Specialist & & \\
\hline Length of working & 52 & 65.8 \\
- <3 year & 10 & 12.7 \\
- 3-5 year & 17 & 21.5 \\
- >5 year & & \\
\hline Motivation & 65 & 82.3 \\
- Good & 14 & 17.7 \\
- Poor & & \\
\hline Performance & 73 & 7.6 \\
- Good & 6 & \\
- Poor & & \\
\hline
\end{tabular}

Research shows that there is more female sex than men. Some respondents have a diploma in education. Most respondents have a work duration of fewer than 3 years. Most respondents are permanent or full-time employees. Judging from the status of marriage shows that most respondents were married. Based on Table 1 it is known that most of the work motivation of hospital employees is in the high category. There are no employees in the low category. The performance shows that most employees have high performance with a percentage reaching $92.4 \%$ and only $7.6 \%$ of employees have moderate performance. There are no employees in the low-performance category. From Table 2, it can be seen that the majority of respondents in this study were nurses/nurse assistants. Then followed by doctors and administrative staff.

Table 2. Data on the profession frequency of hospital employee respondents in 2019

\begin{tabular}{lcc}
\hline \multicolumn{1}{c}{ Profession } & $\mathbf{n}$ & \% \\
\hline Nurse / Assistant nurse & 27 & 34.2 \\
\hline Doctor & 11 & 13.9 \\
\hline Administration & 11 & 13.9 \\
\hline Maintenance / security & 8 & 10.1 \\
\hline A household & 7 & 8.9 \\
\hline Pharmacist / Assistant Pharmacist & 6 & 7.6 \\
\hline
\end{tabular}




\begin{tabular}{llll}
\hline Health analyst & 4 & 5.1 \\
\hline Radiographer & & 3 & 3.8 \\
\hline Midwife & Total & 2 & 2.5 \\
\hline & & 79 & 100 \\
\hline
\end{tabular}

Table 3. Effect of work motivation on hospital employee performance in 2019

\begin{tabular}{lcc}
\hline \multirow{2}{*}{ Variable } & \multicolumn{2}{c}{ Employee performance } \\
\cline { 2 - 3 } & $\mathrm{R}$ & $\mathbf{S i g}(\mathbf{p})$ \\
\hline Work motivation & 0,775 & 0.00 \\
\hline Intrinsic Motivation & 0,737 & 0.00 \\
- Responsible & 0,242 & 0.032 \\
- Recognition & 0,349 & 0.002 \\
- Work performance & 0,301 & 0.007 \\
- Career development & 0,505 & 0.000 \\
- Employment & 0,270 & 0.016 \\
- Job promotion & 0,246 & 0.029 \\
\hline Extrinsic Motivation & 0,325 & 0.03 \\
- Working conditions & 0,375 & 0.001 \\
- Work relationship & 0,086 & 0.453 \\
- Salary & 0.098 & 0.388 \\
\hline
\end{tabular}

In Table 3 the correlation coefficient ( $r$ ) of 0.775 is known to be significant (p) 0.00 smaller than (0.05). Then concluded, there is a strong influence between motivation on the performance of hospital employees. The intrinsic and extrinsic motivation factors depicted in table 3 above provide information about intrinsic motivation having a correlation coefficient (r) of 0.737 with a significant $(p)$ 0.00 less than (0.05), so it is concluded that there is a strong influence of intrinsic motivation on hospital employee performance. While between extrinsic motivation and employee performance there is a low influence with a correlation coefficient (r) of 0.325 . In Table 3, it is known that the intrinsic motivation sub variable has a moderate influence between career development on employee performance with a correlation coefficient (r) of 0.505 . While other intrinsic motivational sub-variables show a low influence on employee performance, namely recognition $(\mathrm{r}=0.349)$, work performance $(r=0.301)$, work $(r=0.270)$, promotion $(\mathrm{r}=0.246)$ and responsibility for value (r) amounted to 0.242 . Table 3 shows the effect of the sub-variable extrinsic motivation of employees on employee performance. Subvariable working conditions have a low influence on employee performance with a correlation coefficient ( $r$ ) of 0.375 . Whereas the sub variable work relationship and salary do not influence employee performance in the hospital.

\section{DISCUSSIONS}

This study found a strong influence between motivation on employee performance. The close influence of work motivation on employee performance must receive special attention to management. Because good employee performance can also be a factor in improving hospital performance because 
employees are the main door in health services to the community. High work motivation can make employees have a high enthusiasm to provide the best service for patients so that patients feel satisfied with the services provided. Efforts are needed to maintain the work motivation of employees so that they remain at a high level so that it will have a positive impact on the future development of the hospital. Employees will be motivated if their wants and needs are met. There is a strong relationship between motivation and performance, the higher the work motivation, the better the performance will be (Janus et al., 2008).

When viewed from each sub variable intrinsic and extrinsic motivation produces a variety of variations. Intrinsic motivation subvariables consisting of responsibility, recognition, work performance, career development, work, and promotion results obtained in general all intrinsic motivation subvariables influence employee performance. Intrinsic motivational factors in the form of opportunities to obtain education/career development, the extent of work received is an important factor for doctors to improve their performance which results in job satisfaction (Janus et al., 2008). Intrinsic motivational factors can influence opportunities for promotion that can improve one's performance because one's performance is measured in terms of their opportunities for promotion (Kunaviktikul, Nuntasupawat, Srisuphan, \& Booth, 2000).

In general, there is a strong influence on work motivation on employee performance. The same result was also obtained from Samba (2020) that there was a positive relationship between work motivation and nurse performance, the higher the motivation, the better their performance (Samba, 2000). Working conditions become the most important sub-variable extrinsic motivation that can affect employee performance. There needs to be attention to the working conditions of the employees so that their work motivation can be maintained properly. Working conditions are greatly influenced by the availability and functioning of the equipment, comfort, and safety of the workplace (Ilyas, 2002).

The better working conditions, work relationships and employee salaries can keep employees motivated to carry out their respective duties. Of all the explanations above, intrinsic motivational factors need to be considered more because they have a stronger influence than extrinsic motivational factors in increasing employee work motivation. While extrinsic motivation is only limited to maintaining employee motivation to keep working properly. Because of the higher the intrinsic motivation, the better the employee's performance. Employees assume that responsibility, recognition, work performance, career development, work, promotion opportunities are more important in improving them so that they remain motivated at work compared to factors of work conditions, work relationships, and salaries. The same research states that aspects of work and promotion opportunities affect someone to continue working there and can affect job satisfaction which can improve nurse performance (Wahyuni, 2005).

\section{CONCLUSIONS}

There is an influence of work motivation on employee performance at the hospital. There is an influence of intrinsic motivation and extrinsic motivation on employee performance in the hospital. There is an influence of intrinsic motivation sub-variables (responsibility, recognition, work performance, career development, work, promotion) on employee performance at the hospital. Career development has the highest influence compared to other intrinsic motivational sub-variables. There is no 
influence of extrinsic motivation sub-variables (work relationship and salary) on employee performance at the hospital. There is a subvariable effect of working conditions on extrinsic motivation on employee performance at the hospital.

From the results of this study, we advise the hospital management to continue to maintain a high level of employee motivation and increase employee motivation. Intrinsic motivation must be considered more to increase work motivation. Providing broader opportunities for employees to continue to develop and get more open opportunities for promotion. Improve hospital working conditions so that employees feel safe and comfortable at work. Increase support from superiors, especially for the progress and success of employees. Then the employee's performance will remain at the highest level that can have a positive impact on hospital development going forward. It is also hoped that research on the effect of motivation and workload on performance will continue to be carried out so that health services can be maintained well.

\section{REFERENCES}

Badi'ah, A. (2009). Hubungan Motivasi Perawat Dengan Kinerja Perawat Di Ruang Rawat Inap Rumah Sakit Daerah Panembahan Senopati Bantul Tahun 2008. Jurnal Manajemen Pelayanan Kesehatan, 12(02). Retrieved from https://jurnal.ugm.ac.id/jmpk/article/view/2 555

Bowling, N. A., Alarcon, G. M., Bragg, C. B., \& Hartman, M. J. (2015). A meta-analytic examination of the potential correlates and consequences of workload. Work and Stress, 29(2), 95-113. https://doi.org/10.1080/02678373.2015.103 3037

Demerouti, E., Nachreiner, F., Bakker, A. B., \& Schaufeli, W. B. (2001). The job demands- resources model of burnout. Journal of Applied Psychology, 86(3), 499-512. https://doi.org/10.1037/00219010.86.3.499

Hakanen, J. J., Bakker, A. B., \& Schaufeli, W. B. (2006). Burnout and work engagement among teachers. Journal of School Psychology, 43(6), 495-513. https://doi.org/10.1016/j.jsp.2005.11.001

Ilyas, Y. (2002). Kinerja Teori Penilaian \& Penelitian. Depok: Pusat Kajian Ekonomi Kesehatan FKM UI.

Janus, K., Amelung, V. E., Baker, L. C., Gaitanides, M., Schwartz, F. W., \& Rundall, T. G. (2008). Job satisfaction and motivation among physicians in academic medical centers: Insights from a crossnational study. Journal of Health Politics, Policy and Law, 33(6), 1133-1167. https://doi.org/10.1215/03616878-2008035

Kawada, T., Ueda, H., Hayashi, M., Sakamoto, A., Uchida, K., Shirato, T., \& Etoh, R. (2010). Relationship among workload, health complaints, and depressive state of workers as revealed using a questionnaire survey. Work, 37(4), 333-339. https://doi.org/10.3233/WOR-2010-1087

Kunaviktikul, W., Nuntasupawat, R., Srisuphan, W., \& Booth, R. Z. (2000). Relationships among conflict, conflict management, job satisfaction, intent to stay, and turnover of professional nurses in Thailand. Nursing and Health Sciences, 2(1), 9-16. https://doi.org/10.1046/j.1442-

2018.2000.00033.x

Mansour, S., \& Tremblay, D.-G. (2016). Workload, generic and work-family specific social supports and job stress. International Journal of Contemporary Hospitality Management, 28(8), 17781804. https://doi.org/10.1108/IJCHM-112014-0607

Nursalam. (2016). Metodologi Penelitian Ilmu 
Keperawatan: Pendekatan Praktis. Jakarta: Salemba Medika.

Rabe, M., Giacomuzzi, S., \& Nübling, M. (2012).

Psychosocial workload and stress in the workers representative. BMC Public Health, 12(1), 909. https://doi.org/10.1186/1471-2458-12-909

Rummell, C. M. (2015). An exploratory study of psychology graduate student workload, health, and program satisfaction. Professional Psychology: Research and Practice, 46(6), 391-399. https://doi.org/10.1037/pro0000056

Samba, S. (2000). Pengantar Kepemimpinan dan Manajemen Keperawatan untuk Perawat Klinis. Jakarta: EGC.

Schaufeli, W. B., \& Bakker, A. B. (2004). Job demands, job resources, and their relationship with burnout and engagement: a multi-sample study. Journal of
Organizational Behavior, 25(3), 293-315. https://doi.org/10.1002/job.248

Tarigan, A. S. U. (2013). Pengaruh Motivasi Terhadap Prestasi Kerja Pegawai Pada Biro Perekonomian Sekretariat Daerah Provinsi Sumatera Utara. Jurnal Administrasi Publik (Public Administration Journal), 3(1). https://doi.org/10.31289/JAP.V3I1.193

van Herpen, M., van Praag, M., \& Cools, K. (2005). The effects of performance measurement and compensation on motivation: An empirical study. Economist, 153(3), 303-329. https://doi.org/10.1007/s10645-005-1990-z Wahyuni, I. (2005). Hubungan antara motivasi, kelelahan kerja dan kepuasan kerja pada perawat RSJD. DR. RM. Soedjarwadi Klaten. Yogyakarta: Universitas Gadjah Mada. 